\title{
Updated programmatic learning outcomes for the training of family physicians in South Africa
}

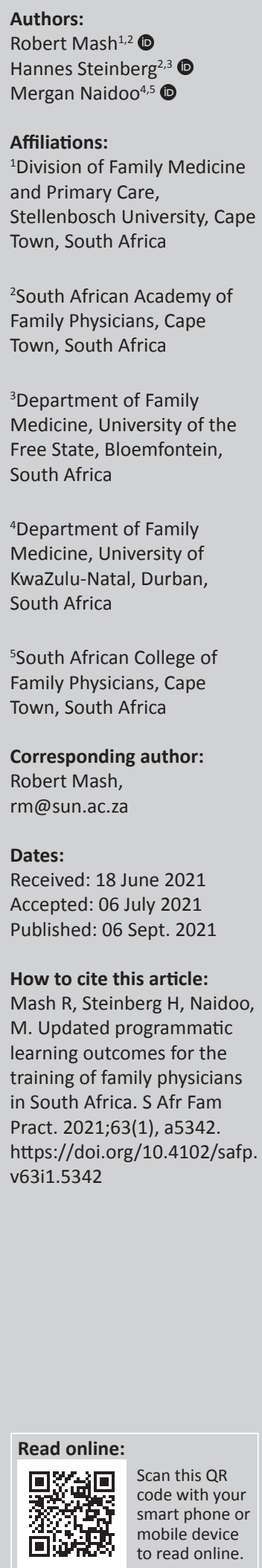

The training of medical specialists should constantly be re-aligned to the needs of the population and the health system. The national Education and Training Committee of the South African Academy of Family Physicians reached consensus on the updated programmatic learning outcomes for the training of specialist family physicians in South Africa. Learning outcomes were first developed to guide training programmes when the speciality was recognised in 2007. Fifteen years later, it was time to revisit and revise these learning outcomes. Learning outcomes define what family physicians are able to do at the end of 4 years of postgraduate training. This revision presents five unit standards and 83 programmatic exitlevel learning outcomes.

Keywords: family physicians; health professions education; learning outcomes; education; curriculum; competency-based education.

\section{Introduction}

The training of medical specialists should constantly be re-aligned to the needs of the population and the health system. ${ }^{1}$ In 2021, the discipline of Family Medicine in South Africa presents an updated set of programmatic learning outcomes for the training of specialist family physicians, which defined what family physicians should be able to do at the end of their 4 years of postgraduate training.

These new outcomes replace the previous ones that were published in 2012. ${ }^{2}$ The original outcomes were developed simultaneously with the recognition of Family Medicine as a new specialty in South Africa in 2007. Over the last 10-years, the discipline has observed the actual competencies expected of family physicians as they engage with patients and the health system, mostly at a primary health care and district hospital level. ${ }^{3}$ The health system has evolved through reengineering and strengthening of primary health care as well as through the piloting of national health insurance as a vehicle to enable universal health coverage. ${ }^{4}$ The landscape of the burden of disease has also shifted with, for example, the human immunodeficiency virus (HIV) epidemic being more controlled through antiretroviral medication and non-communicable diseases, such as diabetes mellitus, becoming more prominent. ${ }^{5}$

During the last 10-years, the university training programmes have coordinated their activities through the South African Academy of Family Physician's national Education and Training Committee (ETC). At the same time, the College of Family Physicians, within the Colleges of Medicine of South Africa, was mandated to run the national licensing examination. Over this period, a number of revisions were already approved, such as new outcomes for training in leadership and clinical governance, ${ }^{6}$ as well as a new list of clinical skills. ${ }^{7}$

The national outcomes should be aligned with the curriculum content, educational approach and forms of assessments within each training programme. These new outcomes will, therefore, have implications for each university. Workplace-based training and assessment is an essential component of all programmes; and a standardised national portfolio of learning has been introduced across all programmes. ${ }^{8}$ This in turn is one of the entry requirements for the licensing examination.

\section{Process of revision}

The previous unit standards and outcomes were included in an electronic questionnaire that went to all training programmes in the country. Each training programme discussed the outcomes 
internally and gave feedback in the questionnaire on the structure of the unit standards and whether to keep, discard or re-phrase each outcome. In addition, every training programme had the opportunity to suggest new learning outcomes. The collated results were presented to the ETC, and all changes and comments were discussed. From the results of the survey, it was recognised that unit standard three, on community-orientated primary care, ${ }^{9}$ needed more extensive revision and careful thought. A sub-group was tasked with re-writing these outcomes completely and presenting the results to the ETC. At the same time, a subgroup, assessing the curriculum content for unit standard four, also made recommendations on revising the learning outcomes. The final set of outcomes were discussed again by the ETC, and a consensus was reached across all training programmes.

\section{Unit standards and learning outcomes}

The five unit standards were retained, but the definitions were revised as shown in Table 1. The learning outcomes for each unit standard are presented in Table 2.

\section{Conclusion}

This open forum article, presents the updated programmatic learning outcomes for training family physicians in South Africa as agreed by the discipline in 2021. Departments of Family Medicine at all universities that train family physicians will need to ensure that their programmes are realigned with these new outcomes. The College of Family Physicians will also need to ensure that in future the blueprinting of their national licencing examination is aligned with the new outcomes. Plans are underway to align the learning outcomes with a set of entrustable professional

TABLE 1: Definitions of unit standards and capabilities required.

\section{Unit standard definitions}

Unit standard 1: Effectively manage themselves, their team and their practice, in any sector, with visionary leadership and self-awareness in order to ensure the provision of high-quality, evidence-based care.

Unit standard 2: Evaluate and manage patients with both undifferentiated and more specific problems in a holistic, cost-effective manner.

Unit standard 3: Improve the health and quality of life of the community.

Unit standard 4: Facilitate the learning of others regarding the discipline of family medicine, primary healthcare, and other health-related matters.
A person who has achieved this standard is capable of effectively managing themselves, their team and their practice, regardless of the sector, shows self-awareness in their personal and professional approach and provides high-quality care based on current evidence

A person who has achieved this standard is capable of evaluating and managing patients, with both undifferentiated and more specific problems, holistically and cost-effectively.

A person who has achieved this standard is capable of leading and implementing integrated and comprehensive communityorientated primary care.

A person who has achieved this standard is capable of educating, teaching, mentoring or supervising others regarding the discipline of family medicine, primary healthcare, and other health-related matters. For example, this may involve the supervision of clinical associates, interns or registrars, teaching of medical students or mentoring of clinica nurse practitioners and junior medical officers. The capability also extends to interaction with community groups and patients.

A person who has achieved this standard is capable of conducting all aspects of healthcare in an ethical, legal and professional manner.
TABLE 2: Programmatic learning outcomes.

\begin{tabular}{|c|c|c|c|}
\hline \multirow{2}{*}{\multicolumn{2}{|c|}{$\begin{array}{l}\text { Unit Standard } \\
\text { Unit standard } 1\end{array}$}} & \multicolumn{2}{|c|}{ Description } \\
\hline & & $\begin{array}{l}\text { Effecti } \\
\text { any se } \\
\text { to ens }\end{array}$ & $\begin{array}{l}\text { ively manage themselves, their team and their practice, in } \\
\text { ctor, with visionary leadership and self-awareness in order } \\
\text { ure the provision of high-quality, evidence-based care. }\end{array}$ \\
\hline 1.1 & $\begin{array}{l}\text { Developing self } \\
\text { optimally as a } \\
\text { leader: }\end{array}$ & $\begin{array}{l}1.1 .2 \\
1.1 .3 \\
1.1 .4\end{array}$ & $\begin{array}{l}\text { Demonstrating self-awareness and reflection in terms } \\
\text { of one's personality, personal values, preferred } \\
\text { learning and leadership styles, and learning and } \\
\text { development needs } \\
\text { Demonstrating effective methods of self-management } \\
\text { and self-care } \\
\text { Demonstrating willingness to seek help, when } \\
\text { necessary } \\
\text { Demonstrating an ability to implement and monitor } \\
\text { strategies for self-growth and personal development }\end{array}$ \\
\hline 1.2 & $\begin{array}{l}\text { Offer leadership } \\
\text { within the } \\
\text { healthcare } \\
\text { team and } \\
\text { district health } \\
\text { system by: }\end{array}$ & $\begin{array}{l}1.2 .1 \\
1.2 .2 \\
1.2 .3\end{array}$ & $\begin{array}{l}\text { Communicating and collaborating effectively } \\
\text { Demonstrating an ability to build capability, mentor or } \\
\text { coach members of the healthcare team } \\
\text { Demonstrating an ability to engage and influence } \\
\text { others through advocacy, group facilitation, } \\
\text { presentations, critical thinking, or behaviour change } \\
\text { counselling } \\
\text { Working effectively as a member of the sub/district } \\
\text { healthcare team }\end{array}$ \\
\hline 1.3 & $\begin{array}{l}\text { Describe and } \\
\text { contribute to } \\
\text { the functioning } \\
\text { of the district } \\
\text { healthcare } \\
\text { system }\end{array}$ & 1.3.1 & $\begin{array}{l}\text { Demonstrating an understanding of the principles of } \\
\text { the district health system in the context of existing and } \\
\text { developing national legislation and policy } \\
\text { Demonstrating an ability to contribute to the } \\
\text { management of a facility, sub-district, or district }\end{array}$ \\
\hline 1.4 & $\begin{array}{l}\text { Lead clinical } \\
\text { governance } \\
\text { activities }\end{array}$ & $\begin{array}{l}1.4 .4 \\
1.4 .5 \\
1.4 .6\end{array}$ & $\begin{array}{l}\text { Demonstrating the ability to lead a quality } \\
\text { improvement cycle in practice } \\
\text { Facilitating reflection on health information (e.g. } \\
\text { monitoring and evaluation, national core standards) in } \\
\text { order to improve quality of clinical care (e.g. rational } \\
\text { prescribing and use of investigations) in the } \\
\text { sub-district/district } \\
\text { Facilitating risk management processes and improving } \\
\text { patient safety (e.g. conduct morbidity and mortality } \\
\text { meetings, assess competence of new clinical staff, } \\
\text { perform root cause analysis, manage patient } \\
\text { complaints) in the sub-district/district } \\
\text { Facilitating the implementation of clinical guidelines in } \\
\text { the sub-district/district } \\
\text { Critically reviewing new evidence (e.g. research) and } \\
\text { applying the evidence in practice } \\
\text { Contributing to the development or revision of } \\
\text { guidelines by generating new evidence (e.g. perform } \\
\text { research) or representing the viewpoint of the district } \\
\text { health services in the process }\end{array}$ \\
\hline 1.5 & $\begin{array}{l}\text { Understand } \\
\text { and influence } \\
\text { corporate } \\
\text { governance }\end{array}$ & $\begin{array}{l}1.5 .4 \\
1.5 .5 \\
1.5 .6 \\
1.5 .7\end{array}$ & $\begin{array}{l}\text { Understand the principles of human resource } \\
\text { management (e.g. labour relations, recruitment, } \\
\text { disciplinary procedures, grievances) } \\
\text { Demonstrate the ability to complete performance } \\
\text { appraisals of staff } \\
\text { Understand the principles of financial } \\
\text { management (e.g. budgets, health economics, } \\
\text { financial planning) } \\
\text { Understand the principles of procurement and } \\
\text { infrastructure (e.g. supply chain, equipment, buildings) } \\
\text { Understand the principles of health information and } \\
\text { record-keeping systems } \\
\text { Understand the principles of rational planning of } \\
\text { health services } \\
\text { Be able to communicate effectively with those } \\
\text { responsible for corporate governance }\end{array}$ \\
\hline Unit & t standard 2 & $\begin{array}{l}\text { Evalua } \\
\text { more }\end{array}$ & $\begin{array}{l}\text { ate and manage patients with both undifferentiated and } \\
\text { specific problems in a holistic, cost-effective manner. }\end{array}$ \\
\hline 2.1 & $\begin{array}{l}\text { Evaluate a } \\
\text { patient } \\
\text { holistically: }\end{array}$ & $\begin{array}{l}2.1 .2 \\
2.1 .3\end{array}$ & $\begin{array}{l}\text { Taking a relevant history in a patient-centred manner, } \\
\text { including exploration of the patient's illness } \\
\text { experiences and context. } \\
\text { Performing a relevant and accurate examination. } \\
\text { Deciding on or performing appropriate special } \\
\text { investigations where indicated, based on current } \\
\text { evidence and balancing risks, benefits and costs. } \\
\text { Formulating a holistic assessment of the patient's } \\
\text { problems, taking into account the biological, } \\
\text { psychological, spiritual, social and contextual issues } \\
\text { Demonstrating sound clinical reasoning at every point } \\
\text { in the consultation. }\end{array}$ \\
\hline 2.2 & $\begin{array}{l}\text { Formulate and } \\
\text { execute, in } \\
\text { consultation } \\
\text { with the patient, } \\
\text { a mutually } \\
\text { acceptable, } \\
\text { cost-effective } \\
\text { management } \\
\text { plan, evaluating } \\
\text { and adjusting } \\
\text { elements of the } \\
\text { plan as } \\
\text { necessary by: }\end{array}$ & $\begin{array}{l}2.2 .3 \\
2.2 .4\end{array}$ & $\begin{array}{l}\text { Communicating effectively with patients to inform } \\
\text { them of the diagnosis or assessment and to seek } \\
\text { consensus on a management plan } \\
\text { Establishing priorities for management, based on the } \\
\text { patient's perspective, biological and socio-economic } \\
\text { preconditions, medical urgency and context. } \\
\text { Formulating a cost-effective management plan and } \\
\text { appropriate safety netting. } \\
\text { Formulating a management plan for patients with } \\
\text { family-orientated or other social problems, making } \\
\text { appropriate use of family and other social and } \\
\text { community support, and resources. }\end{array}$ \\
\hline
\end{tabular}


TABLE 2 (Continues...): Programmatic learning outcomes.



TABLE 2 (Continues...): Programmatic learning outcomes.

\begin{tabular}{|c|c|c|c|}
\hline \multicolumn{2}{|c|}{ Unit Standard } & \multicolumn{2}{|c|}{ Description } \\
\hline & & $\begin{array}{l}4.1 .6 \\
4.1 .7 \\
4.1 .8 \\
4.1 .9 \\
4.1 .10\end{array}$ & $\begin{array}{l}\text { Facilitating small group learning. } \\
\text { Eliciting course evaluation and feedback from } \\
\text { participants or students. } \\
\text { Applying the principles of assessment of learning } \\
\text { Conducting an evidence-based approach to } \\
\text { teaching. } \\
\text { Managing the learner in difficulty. }\end{array}$ \\
\hline Unit & t standard 5 & $\begin{array}{l}\text { Condu } \\
\text { profes }\end{array}$ & $\begin{array}{l}\text { uct all aspects of healthcare in an ethical, legal and } \\
\text { ssional manner. }\end{array}$ \\
\hline 5.1 & $\begin{array}{l}\text { Demonstrate an } \\
\text { awareness of the } \\
\text { legal and } \\
\text { ethical responsibilities } \\
\text { in the provision of } \\
\text { care to individuals } \\
\text { and populations by: }\end{array}$ & $\begin{array}{l}5.1 .5 \\
5.1 .6 \\
5.1 .7\end{array}$ & $\begin{array}{l}\text { Identifying and defining an ethical dilemma using } \\
\text { ethical concepts. } \\
\text { Applying a problem-solving approach in which } \\
\text { the law, ethical principles and theories, medical } \\
\text { information, societal and institutional norms, and } \\
\text { personal value system are reflected. } \\
\text { Formulating possible solutions to the ethical } \\
\text { dilemma. } \\
\text { Implementing these solutions in order to provide } \\
\text { healthcare in an ethical, compassionate and } \\
\text { responsible manner that reflects respect for the } \\
\text { human rights of patients and colleagues. } \\
\text { Demonstrating adherence to Health Professions } \\
\text { Council of South Africa ethical guidelines } \\
\text { Apply relevant law to clinical practice } \\
\text { Demonstrate the ability to effectively manage } \\
\text { patient complaints and advise on medico-legal } \\
\text { risks and media enquiries. }\end{array}$ \\
\hline 5.2 & $\begin{array}{l}\text { Demonstrate } \\
\text { professional values } \\
\text { in relationship } \\
\text { to society, } \\
\text { interpersonal } \\
\text { relationships and } \\
\text { personal } \\
\text { behaviour by: }\end{array}$ & 5.2 .1 & $\begin{array}{l}\text { Demonstrating professional values in relationship } \\
\text { to society, for example, striving for equity in } \\
\text { healthcare delivery, striving for quality in } \\
\text { healthcare delivery and defending the human } \\
\text { rights of patients and colleagues. } \\
\text { Demonstrating professional values in } \\
\text { interpersonal relationships, for example, dealing } \\
\text { courteously with patients, colleagues and the } \\
\text { public, and having regard for cultural issues and } \\
\text { individual dignity. } \\
\text { Demonstrating professional values in personal } \\
\text { behaviour, for example, delivering healthcare of a } \\
\text { consistent high standard irrespective of his or her } \\
\text { own perceptions or prejudices and the } \\
\text { background, with respect to gender, ethnicity, } \\
\text { religion or sexual orientation, of his or her patient. }\end{array}$ \\
\hline
\end{tabular}

CHW, community health worker.

activities and observable practice activities. The outcomes will be revised in 5 years' time.

\section{Acknowledgements}

We acknowledge the other members of the national Education and Training Committee of the South African Academy of Family Physicians who were responsible for updating the learning outcomes: Prof Klaus von Pressentin, Dr Tasleem Ras (University of Cape Town); Dr Ts'epo Motsohi, Dr Zelra Malan (Stellenbosch University); Dr Elizabeth Reji, Prof Hanneke Brits (University of the Free State); Prof Olufemi Omole, Prof Richard Cooke, Ms Deirdre Pretorius (University of the Witwatersrand); Prof Indiran Govender, Dr Olga Maphasha (University of Pretoria); Prof Honey Mabuza, Dr Kefilwe Hlabyago, Dr Nnanile Nyalunga (Sefako Makgatho Health Sciences University); Prof Bernhard Gaede (University of KwaZuluNatal); Dr Mohammad Shoyeb (University of Limpopo); Prof Parimalaranie Yogeswaran, Dr Busisiwe Cawe (Walter Sisulu University); Dr Emmanuel Ajudua, Dr Febi Ajudua (Nelson Mandela University); Dr Chantelle van der Bijl (Registrar representative).

\section{Competing interests}

The authors declare that they have no financial or personal relationships that may have inappropriately influenced them in writing this article. 


\section{Authors' contributions}

R.M., H.S. and M.N., all helped to coordinate the process leading to the updated outcomes. The manuscript was drafted by R.M. and edited by H.S. and M.N. All approved the final version.

\section{Ethical considerations}

This article followed all ethical standards for research without direct contact with human or animal subjects.

\section{Funding information}

This article received no specific grant from any funding agency in the public, commercial or not-for-profit sectors.

\section{Data availability}

Data sharing is not applicable to this article as no new data were created or analysed in this study.

\section{Disclaimer}

This is the official viewpoint of the South African Academy of Family Physicians.

\section{References}

1. Frenk J, Chen L, Bhutta ZA, et al. Health professionals for a new century Transforming education to strengthen health systems in an interdependent world. Lancet. 2010;376(9756):1923-1958. https://doi.org/10.1016/S0140 6736(10)61854-5

2. Couper I, Mash B, Smith S, Schweitzer B. Outcomes for family medicine postgraduate training in South Africa. S Afr Fam Pract. 2012;54(6):501-506. https://doi.org/10.1080/20786204.2012.10874283

3. Mash R, Ogunbanjo G, Naidoo SS, Hellenberg D. The contribution of family physicians to district health services: A national position paper for South Africa. $S$ Afr Fam Pract. 2015;57(3):54-61.

4. Matsoso M, Fryatt R, Andrews G. The South African health reforms, 2009-2014: Moving towards universal coverage [homepage on the Internet]. Cape Town: Juta; 2015 [cited 2018 Dec 18]. Available from: https:/scholar google co.za/ 2015 [cited 2018 Dec 18]. Available from: https://scholar.google.co.za/ scholar?hl=en\&as_sdt=0\%2C5\&q=South-African-Health-Reforms-2009-
2014\&btnG $=$

5. StatsSA. Key findings P0309.3 - Mortal and causes of death in South Africa: Findings from death notification, 2015 [homepage on the Internet]. 2018 [cited 2019 Mar 26]. Available from: http://www.statssa.gov.za/?page id =1856\& $\mathrm{PPN}=\mathrm{P0309.3 \& SCH=6987}$

6. Mash R, Blitz J, Malan Z, Von Pressentin K. Leadership and governance: Learning outcomes and competencies required of the family physician in the district health system. S Afr Fam Pract. 2016;58(6):232-235. https://doi.org/10.1080/20786190 2016.1148338

7. Akoojee Y, Mash R. Reaching national consensus on the core clinical skill outcomes for family medicine postgraduate training programmes in South Africa. Afr Prim Health Care Fam Med. 2017;9(1):a1353. https://doi.org/10.4102/phcfm. v9i1.1353

8. Jenkins L, Mash B, Derese A. The national portfolio for postgraduate family medicine training in South Africa: A descriptive study of acceptability, educational impact, and usefulness for assessment. BMC Med Educ. 2013;13:101. https://doi org/10.1186/1472-6920-13-101

9. Mash R, Gaede B, Hugo JF. The contribution of family physicians and primary care doctors to community-orientated primary care. S Afr Fam Pract. 2021;63(1):5281. doctors to community-orientated primary
https://doi.org/10.4102/safp.v63i1.5281 